\title{
Perceptions and relationships to school resources and academic achievement: Implications for the principal as instructional leader
}

\section{Boudreaux, Mary Keller}

Department of Leadership, University of Memphis,USA (

Martin, Rosalind

Shelby County Schools, USA (MARTINRR@ scsk12.org)

McNeal, Larry

Department of Leadership, University of Memphis, USA (Lmcneal1@memphis.edu)

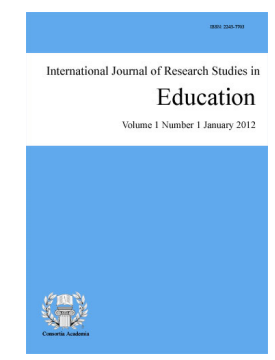

ISSN: $2243-7703$ Online ISSN: 2243-7711

OPEN ACCESS

\section{Abstract}

Multiple elements help to define school climate and its dimensions. The focus of an effective school climate is often on relationships/quality interactions, parental/community involvement, order and discipline, trust and feelings of safety, and classroom overcrowding. However, there is insufficient research on the elements of school resources and the relationship to student academic achievement. There are even fewer studies on teachers' perceptions of this element and its affect student achievement. The researchers used secondary data to analyze teachers' perceptions related indices of school resources and its direct relationship to student academic achievement. According to the data results, there were no significant differences between elementary and middle school teachers' perceptions about access to resources. However, there was a difference in teachers' perceptions who worked in schools with proficient reading and math scores on standardized test.

Keywords: school climate; school resources; school leadership 


\section{Perceptions and relationships to school resources and academic achievement: Implications for the principal as instructional leader}

\section{Introduction}

With the enactment of the No Child Left Behind Act (NCLB) in 2001, school districts are under pressure to find effective means to continue to improve student performance. Federal and state laws rely on multiple indicators to measure and improve performance such as teacher accountability, annual student assessments, and progress reports. However, inadequate attention is directed at school climate as a means to improve student academic achievement even though there is a diverse body of research linking school climate to student achievement and academic performance (Kober, 2001; Loukas \& Robinson, 2004; Shindler, Jones, Taylor, \& Cadenas, 2004). Although there is not a singular definition for school climate, most researchers agree that a positive school climate exists when all students feel comfortable, wanted, valued, accepted, and secure in an environment where they can interact with caring people they trust (Loukas \& Robinson, 2004). Collectively and individually, a positive school climate can have a major impact on the success of all students in the school (Loukas \& Roalson, 2006). Moreover, a positive school climate can have a major impact on teachers and their job satisfaction and efficacy (Taylor \& Tashakkori, 1995).

Climate is also a major part of teacher working conditions (Cohen, 2009). The importance of teacher working conditions is magnified by the teacher attrition problems plaguing schools-especially in the United States' chronically hard-to-staff urban and rural schools (Darling-Hammond, 2003). According to Learning First Alliance (LFA), basic working conditions in high-poverty, low-performing schools are often far worse than any professional should be asked to tolerate, and it is hardly surprising that such conditions are a major cause of high teacher turnover in many urban schools (Emerick, Hirsch, \& Barry, 2005). The report establishes that even excellent teachers struggle when faced with a lack of resources (Emerick, Hirsch, \& Barry, 2005).

One of the most critical issues facing school districts in the common core era is a paucity of resources. Instructional resources should be readily available to all teachers. Textbooks, technology, and instructional supplies, required office equipment should be easily accessible to teachers. With the implementation of Common Core State Standards in 2009 and adoptions by all but four states in 2010 and 2011, a lack of instructional resources have also been unavailable for student use in schools, i.e., computers in classrooms. PARCC and Smarter Balanced were two consortia of choice in student performance assessments for states and their school districts (Gerwetz, 2014). Such performance assessments require student use of technology. Although Gerwetz (2014) reports that by mid-2014 states utilized alternative exams rather than the two consortia, the lack of instructional resources such as technology to assess student academic performance on state mandated tests remained problematic due to lack of state funding, particularly in large urban school districts.

Human resources, is another area of critical shortage facing school districts. School districts struggle to find funding to hire support staff to assist in improving instruction and student learning in classrooms. As such, Plecki, Knapp, Castaneda, Halverson, LaSota, and Lochmiller, (2009) advocate that new innovative ideas in the allocation of school funds for quality teaching and learning. The authors contend, "district and school leaders have recognized that investing staffing resources in learning improvement means more than getting people into positions, especially new and unfamiliar positions" (p. viii).

As noted in the aforementioned paragraphs, several factors can have a positive impact on urban education and level the field for improving student achievement. One particular is school resources. While various states are facing a scarcity of funding for resources, there seems to be a dearth of research being done on the relationship between school resources and the academic achievement of students. Therefore, the purpose of this study is to examine teachers' perceptions of the school climate dimension of school resources and the direct 
relationship to student academic achievement in an urban school district.

\subsection{Theoretical Framework}

Herzberg's (1959) theory serves as the primary theory for this study and provides context for the various factors that lead to teachers' job satisfaction and dissatisfaction. The key to understanding Herzberg's Motivation-Hygiene Theory (Herzberg, 1966) is that the factors that involve job contentment (motivational factors) can lead to job satisfaction; in as much, satisfied workers are willing to work harder and go beyond the standard when needed which can result in increased productivity. According to Herzberg (1959), one particular motivator, the work itself, is the actual content of the job and its effect on the employee as determined by whether the job is characterized as interesting or boring, varied or routine, creative or stultifying, excessively easy or excessively difficult, challenging or non-demanding. In the education field, this translates to a satisfied teacher being willing to work extra hours and dedicate more time and energy to pursue common outcomes with school administrators and students.

\subsection{Resources Accessibility}

Teachers' perceptions of their working conditions are affected by the amount and quality of the resources that are available to them (Marvel, Lyter, Peltola, Strizek, \& Morton, 2007). Reform efforts encourage that school resources are directly aligned to instructional improvement (Plecki, Knapp, Castaneda, Halverson, LaSota, \& Lochmiller, 2009). A report supported by the Wallace Foundation indicated that resources should be invested across schools and districts equitably (Plecki et al., 2009). In fact, the report by the Wallace Foundation states that four key principles are key to equitable student learning: (1) identifying where and how resources can support gap-closing activities; (2) Organizing schools to enable the alignment of resources with learning improvement; (3) Developing the human capital of the school or district; and, (4) Managing the politics of learning-focused resource investment (pp. 5-6). In essence, look for ways to close the achievement gap, look for alternative practices and ways to invest resources that are productive for all stakeholders involved, provide strong developmental practices for all educational stakeholders vested in the school system, and making smart investment decisions regarding the allocation of resources.

When considering physical resources, one may consider examining the teachers' perceptions about resources as a mean for effective teaching. Teachers consider resources such as instructional materials, technology, and supplies, as a means to academic achievement. For example, Freeman and Porter (1989) examined teacher access to instructional materials and reported that textbooks and instructional materials are the primary tools that teachers use to organize their lessons, build content knowledge, and improve critical thinking skills of students. These textbooks and workbook materials contain the content that students are expected to learn, and most teachers focus their instruction on the material included in the books they use.

In a national report of $4^{\text {th }}$ through $12^{\text {th }}$ graders' use of technology for learning, Pearson (2014) initiated The Pearson Student Mobile Device Survey and found that $93 \%$ of students in schools have more Internet access at home than in their classrooms. That is, only $62 \%$ have internet in their schools. Overall, there is an increase in student usages of tablets and smartphones in classrooms. Yet, elementary and middle school students purport the use of a shared classroom computer. Interestingly, the survey indicated that "three quarters of high school students say they know more about technology than their teachers (p. 19).

A research report conducted by Moeller and Reitzes (2011) and funded by the Nellie Mae Education Foundation included findings regarding technology integration geared towards student-centered learning. The report noted that despite the readily available technology in schools and classrooms, few teachers (eight percent) actually integrate and expand the use of technology in their teaching. The report highlighted that "most teachers lack confidence in technology as well as their technology skills" (p. 7). In order to create a more student-centered classroom and school, new innovative approaches to teaching and learning with technology will provide a means for full integration in classrooms. Such innovations include blended courses and the use of 
online tutors for synchronous (online teaching in real time) and asynchronous (delayed online teaching) platforms to advance student learning.

Findings on a survey conducted by the National Education Association (2008) claimed that "the number of computers in public school classrooms was not adequate to use computers effectively for classroom instruction" (p. 9). The report included recommendations to improve both student and teacher access to technology in the classroom, the implementation of technology in the curriculum and professional development geared towards training educators (p. 6). In support of such findings, a survey conducted by ACT reported that five conditions in the literature crucial to technology implementation include: (1) technology is best used as one component in a broad-based reform effort; (2) teachers must be adequately trained to use technology; (3) technological resources must be sufficient and accessible; (4) effective technology use requires long-term planning and support, and (5) technology should be integrated into the curricular and instructional framework (Noeth \& Volkov, 2004, p. 8).

Educators often consider computers and computer software as the most essential form of instructional resources, but instructional technologies are not limited to computers in the classroom. Seels and Richey (1994) defines instructional technology as the theory and practice of design, development, utilization, management and evaluation of processes and resources for learning. Likewise, Seels and Richey (1994) stress that cameras, CD players, PDA's, GPS devices, computer-based probes, calculators and electronic tools are all instructional technologies. However, the instructional technologies that are used regularly for teaching and learning in middle schools are: internet access, computers, printers, and software (Pitler, 2007). These technological resources have unique functions in the classroom to support student learning, assign school assignments, and to assist students in gaining a better understanding of information; and, teachers also believe this resource is best used to enrich instructional programs for high achieving students as well as remediation and practice for all students (Pitler, 2007).

\subsection{Sufficient Access to Office Equipment and Supplies}

According to the 2011 Kentucky Teaching Empowering Leading and Learning (TELL) Survey, one hundred percent of teachers in Cairo Elementary School reported that they have sufficient access to office equipment and supplies. While teachers feel like essential supplies such as paper, pencil, and makers should be provided by the schools in order to ensure the curriculum is effectively taught (Johnson \& National Education Association, 2006); such resources lack availability in many states. According to an article in the Time U.S magazine students were welcomed back to school in a budget-strapped California, where pencils, paper and textbooks are indeed prized goods-and their availability in classrooms is increasingly dependent upon the resourcefulness of teachers (Kloberdanz, 2010). As a matter of financial survival, teachers asked for donations via websites, clipped coupons and learned how to make use of second-hand items. The article reported that teachers even used recycled worksheet paper because such needed resources were not readily available in the school to meet the needs of the students. When circumstances require educators to respond to deficits of supplies in such a manner, behaviors of the sort can shape one's perception of the working conditions and reduce productivity, or student outcomes.

\subsection{Professional Support Personnel}

In most schools in this nation, school districts, specifically, low income schools have access to human support resources that tend to make a difference in student outcomes. York and Vandercrook (1990) define Educational Support Personnel (ESP's) as the support staff members that work with teachers and students inside and outside the classroom. In addition to instructional support, teachers need educational personnel support. Some of the ESP's in large school districts are school psychologist, school social workers, therapists, special education supervisors, literacy coaches, and school nurses (York \& Vandercrook, 1990). The ESP's are professionally trained individuals that assist teachers, students, and parents with everything from medical conditions to counseling. The type and intensity of professional personnel support varies. York, Giangreco, Vancercook, and McDonald (1992) add that the following types of support systems are necessary and available and serve as key resources to the educational process: resource support, moral support, technical support, and 
evaluation support.

\subsection{Resources and Academic Achievement}

Although there has been no clear relationship between resource allocation and student success (Rennie Center for Education Research \& Policy, n.d.), the Southwest Educational Development Laboratory (SEDL) conducted a study to examine district level patterns of resource practices to improve school performance (Pan, Rudo, Schneider, \& Smith-Hansen, 2003). The results "demonstrated a strong relationship between resources and student success" (p. vi). One particular recommendation based upon the findings in this research endeavor included, "prioritizing resources towards professional development, realigning staffing structures to accommodate the strengths and weaknesses of existing staff, and finding ways to recruit and retain quality staff through compensation and support systems" (p. viii). Basically, allocation of funds should be a systematic approach tied to innovative school reform processes to support student success and performance.

The Rennie Center for Education Research and Policy (n.d.) cites a meta-analysis of over 400 research studies between school resources and outcomes. The findings are inconclusive offering very little substantiated evidence of a direct correlation between school resources and student performance. However, the meta-analysis provided an analysis of common problems facing school budgeting: targeting achievement gaps; alignment of resources to support learning improvement agendas; managing the politics of learning-focused leadership; and, developing the human capital of the school or district (p. 3).

The aforementioned support systems provided are examples of the resources needed in schools to create comfortable working conditions which could motivate teachers and aid in developing a positive image of urban schools. Whereas, the related studies focused on school resources in a school setting, the authors of this particular study address their concerns regarding school resources in a diverse, urban school district. As noted earlier, several studies identify resources and a clear relationship to school improvement; however, there is little information on student achievement in reading and mathematics. The goal of this research is to examine teachers' perceptions of five tenets related to school resources and the relationship between these school resources and academic achievement.

\subsection{Research Questions}

According to Tashakkori and Teddlie (1998), research is usually categorized in terms of the general methodology. The researchers add that in educational studies, the researcher may employ the use of qualitative, quantitative, experimental, or non-experimental methodology to frame his study. Questionnaires, tests, records, standardized observation instruments, and existing data bases can serve as an appropriate source for data when utilizing the quantitative approach to research (Patton, 2007). The quantitative approach utilizes data from human samples and places the data in predetermined categories for statistical analysis (Creswell, 2008). This method of research allows the researcher to study specific questions, collect quantifiable data from selected participants, and analyze the information gathered using statistical procedures. The result is an unbiased and objective interpretation of data (Creswell, 2008). For the purpose of this study, the researcher will use a quantitative approach to organize the methodology.

The researchers submitted two specific questions to be answered by this study. In order to answer the research, this study will use a quantitative methodology that facilitates an analysis of the variables in the study. The quantitative methodology will be a useful research design for explaining variables and the relationship among them (Creswell, 2008). The researchers determined that a non-experimental approach utilizing descriptive and correlational statistics will be the most appropriate for a secondary data analysis study. The study is guided by the following two research questions:

$>\quad$ How do urban elementary and middle school teachers perceive the level of access to resources at their schools and do these perceptions differ by school type? 
$>\quad$ What relationships are observed between urban elementary and middle teachers' perceptions of their access to resources and student achievement in reading and math?

\section{Method}

This study presents the results of a secondary data analysis of 2565 elementary school and 888 middle school teacher responses on one section of the Measures of Effective Teaching/Working Conditions Survey (MET), regarding instructional resources as they impact school climate and ultimately student achievement.

\subsection{Participants}

Schools in this study were elementary and middle schools, all located in a large district in the Southeastern United States which was selected based on the grade configuration. The total enrollment for the large urban district was 102, 798 students in 2009 school year. School sizes varied from 248 to 1007 in the elementary schools, with a mean enrollment of 677. Economically disadvantaged status at the school level was determined by the percentage of students eligible for free or reduced lunch, which ranged from $15 \%$ to $96 \%$. School sizes varied from 248 to 1007 in the elementary schools, with a mean enrollment of 677 . The teacher sample consisted of elementary and middle school teachers. The MET (Measures of Effective Teaching) Working Conditions Survey was administered to 4596 teacher respondents at 206 district "sites" (Swanlund, 2011). The results are displayed in Table 1. To assess the degree to which the MET Working Conditions Survey measures teachers' perceptions of the student academic achievement indices of school resources; the Statistical Package for Social Sciences (SPSS) version 23 was used to perform the secondary data analysis that was used for this study. A secondary analysis is further analysis of an existing data-set which presents interpretations, conclusions, or knowledge additional to, or different from, those presented in the first report on the data collection and its results.

Table 1

Demographic of Teacher Respondents to the 2010 Teaching Working Conditions Survey $(N=4596)$

\begin{tabular}{|c|c|c|c|c|c|}
\hline Groups & $\begin{array}{c}\text { All } \\
(N=4596) \\
\%\end{array}$ & $\begin{array}{c}\text { Elem } \\
(n=2565) \\
\%\end{array}$ & $\begin{array}{c}\text { Middle } \\
(n=888) \\
\%\end{array}$ & $\begin{array}{c}\text { High } \\
(n=979) \\
\%\end{array}$ & $\begin{array}{c}\text { Others } \\
(n=164) \\
\%\end{array}$ \\
\hline \multicolumn{6}{|c|}{ Total Years Employed as an Educator: Teachers } \\
\hline First year & 5.2 & 3.0 & 7.0 & 9.1 & 6.7 \\
\hline 2 to 3 years & 9.5 & 6.9 & 12.2 & 14.0 & 9.8 \\
\hline 4 to 6 years & 11.9 & 9.2 & 17.6 & 13.4 & 14.6 \\
\hline 7 to 10 years & 17.8 & 18.6 & 17.7 & 16.5 & 12.8 \\
\hline 11 to 20 years & 29.4 & 33.1 & 25.8 & 24.0 & 22.6 \\
\hline $20+$ years & 26.0 & 29.0 & 19.5 & 22.7 & 33.5 \\
\hline Not answered & 0.3 & 0.2 & 0.3 & 0.3 & 0.0 \\
\hline \multicolumn{6}{|c|}{ Total Years Employed at Present School: Teachers } \\
\hline First year & 14.1 & 10.4 & 15.1 & 21.6 & 22.6 \\
\hline 2 to 3 years & 19.5 & 16.2 & 26.4 & 23.3 & 9.8 \\
\hline 4 to 6 years & 20.4 & 20.2 & 23.8 & 18.6 & 17.7 \\
\hline 7 to 10 years & 16.9 & 19.9 & 14.3 & 12.3 & 12.8 \\
\hline 11 to 20 years & 16.2 & 19.0 & 11.8 & 12.4 & 17.7 \\
\hline $20+$ Years & 7.7 & 9.0 & 4.1 & 6.9 & 11.6 \\
\hline Not answered & 5.2 & 5.3 & 4.6 & 5.0 & 7.9 \\
\hline
\end{tabular}

\subsection{Instrument}

The MET Working Conditions Survey analyses presented are based on the responses to a survey instrument that was based on the North Carolina Teacher Working Conditions Survey (Hirsch \& Church, 2009), but customized to Tennessee. Examining the validity of the MET Working Conditions Survey addresses questions of 
whether the instrument is a true measure of what it is attempting to assess; in this case, the presence of teaching conditions (Swanlund, 2011). Reliability and validity represent the key trustworthy tests that teachers and education leaders are applying as they create new systems of teacher evaluation, so they also represent the key questions the MET project is designed to investigate.

The MET Survey is considered "reliable" when it shows "inter-rater reliability" - that is, when two people using the same measure to evaluate the same teacher come up with the same results. "Valid" teaching effectiveness measures are those that are proven to lead to student learning. Many current evaluation systems, by contrast, are subjective observations based on checklists of teaching practices that have not been demonstrably linked to promoting student learning.

The 3,000 teacher volunteers participating in the project agreed to be evaluated - for research purposes only — using the teaching effectiveness measures being studied (Swanlund, 2010). The MET project validates all its measures against the difference between actual and expected student achievement on standardized tests using a method called "value-added." A teacher's value-added score is determined by comparing the achievement gains made by his or her students to those made by teachers with students with similar characteristics, including similar prior achievement levels. By comparing a teacher's value-added scores with his or her results on the other measures of teaching effectiveness being examined by the study, MET project researchers can investigate which teaching practices, and which teaching effectiveness measures, best predict achievement gains.

The researchers used secondary data to analyze teachers' perceptions of student academic achievement related indices of instructional resources and their relationship to student academic achievement. Secondary data analysis is an analysis of an existing data-set which presents interpretations, conclusions, or knowledge additional to, or different from, those presented in the first report on the data collection and its results. By using secondary data, a more complete and comprehensive assessment of teacher working conditions will be determined. The goal of descriptive statistics is to describe the groups, while the goal of co-relational statistics is to identify the relationship among the variables (Leedy \& Ormrod, 2012, p. 296).

\subsection{Data Analysis}

A descriptive analysis was performed on the sample group to obtain a clear understanding of the group. Measures of central tendency and distribution was conducted. The researchers determined means, medians, and percentiles based on the data input. Standard deviations will also be determined during data analysis and reported as well. This quantitative study used correlation analysis to analyze the data. In the correlation analysis, the researchers were able to determine the strength of the relationships between resources and student achievement.

\section{Findings}

Research question 1 pertains to how urban elementary and middle school teachers perceive the level of access that they have to resources at their schools and whether such perceptions differ by school type. With respect to this question, frequencies and percentages were obtained for each of five "resource-related" items on the MET/Working Conditions Survey for all elementary school teacher respondents (Table 2) and middle school teacher respondents (Table 3). Complementing these two tables of frequencies and percentages are two additional tables in which means and standard deviations have been computed and compared for subgroups of elementary and middle school teachers given the responses of individuals as the unit of analysis (Table 4) and responses aggregated to the school- or faculty-level as the unit of analysis (Table 5). With all of these responses pertinent to the availability of resources for improving a climate of academic achievement in schools, these five "resource-related" items read as follows:

$>$ Teachers have sufficient access to appropriate instructional materials.

$>$ Teachers have sufficient access to instructional technology, including computers, printers, software 
and internet access.

$>$ Teachers have access to reliable communication technology, including phones, faxes and email.

$>\quad$ Teachers have sufficient access office equipment and supplies such as copy machines, paper, pens, etc.

$>\quad$ Teachers have sufficient access to a broad range of professional support personnel.

As shown in Table 2, the highest level of agreement among elementary teachers was observed for the resource-related item concerning "access to reliable communication technology, including phones, faxes, and email" (87.0\%). Nearly as high was the level of elementary school teacher agreement to the item concerning teacher "access to appropriate instructional materials" (79.4\%). While still above 70\%, the lowest level of agreement among elementary school teachers was with respect to the resource-related item dealing with "access to instructional technology, including computers, printers, software, and internet access" (70.7\%).

As shown in Table 3, the level of agreement/strong agreement to the resource-related items among middle school teachers was similarly high. Some $85.3 \%$ of the middle school teachers indicated that they had "access to reliable communication technology, including phones, faxes, and email," while nearly that same percentage indicated that their "access to a broad range of support personnel" was sufficient. In contrast, only $61.2 \%$ of middle school teachers reported that they had "sufficient access to instructional technology, including computers, printers, software and internet access" roughly $9.5 \%$ fewer than was observed for elementary school teachers.

In general, as shown in Tables 4 and 5, the item means observed for elementary and middle school teachers with respect to resources trend higher for the former group, the only exception being the item concerning office equipment. As indicated in Table 5, no significant differences were observed between teacher groups for any resource-related item or the five-item scale taken as a whole.

\section{Table 2}

Frequencies and Percentages for Resource-Related Items: Elementary Level Respondents

\begin{tabular}{|c|c|c|c|c|c|c|c|c|c|c|}
\hline \multirow{2}{*}{ Item } & \multicolumn{2}{|c|}{$\begin{array}{l}\text { Strongly } \\
\text { Disagree }\end{array}$} & \multicolumn{2}{|c|}{ Disagree } & \multicolumn{2}{|c|}{ Agree } & \multicolumn{2}{|c|}{$\begin{array}{c}\text { Strongly } \\
\text { Agree }\end{array}$} & \multicolumn{2}{|c|}{ NA } \\
\hline & $n$ & $\%$ & $n$ & $\%$ & $n$ & $\%$ & $n$ & $\%$ & $n$ & $\%$ \\
\hline $\begin{array}{l}\text { Teachers have sufficient access } \\
\text { to appropriate instructional } \\
\text { materials. }\end{array}$ & 48 & .4 & 398 & 14.4 & 1548 & 56.0 & 646 & 23.4 & 25 & 0.9 \\
\hline $\begin{array}{l}\text { Teachers have sufficient access } \\
\text { to instructional technology, } \\
\text { including computers, printers, } \\
\text { software and internet access. }\end{array}$ & 221 & 8.0 & 557 & 20.1 & 1332 & 48.2 & 621 & 22.5 & 34 & 1.2 \\
\hline $\begin{array}{l}\text { Teachers have access to reliable } \\
\text { communication technology, } \\
\text { including phones, faxes and } \\
\text { email. }\end{array}$ & 86 & 3.1 & 250 & 9.0 & 1641 & 59.3 & 767 & 27.7 & 21 & 0.8 \\
\hline $\begin{array}{l}\text { Teachers have sufficient access } \\
\text { to office equipment and supplies } \\
\text { such as copy machines, paper, } \\
\text { pens, etc. }\end{array}$ & 293 & 10.6 & 576 & 20.8 & 1308 & 47.3 & 563 & 20.4 & 25 & 0.9 \\
\hline $\begin{array}{l}\text { Teachers have sufficient access } \\
\text { to a broad range of professional } \\
\text { support personnel. }\end{array}$ & 191 & 6.9 & 446 & 16.1 & 1510 & 54.6 & 572 & 20.7 & 46 & 1.7 \\
\hline
\end{tabular}


Perceptions and relationships to school resources and academic achievement

Table 3

Frequencies and Percentages for Resource-Related Items: Middle Level Respondents

\begin{tabular}{|c|c|c|c|c|c|c|c|c|c|c|}
\hline \multirow[t]{2}{*}{ Item } & \multicolumn{2}{|c|}{$\begin{array}{l}\text { Strongly } \\
\text { Disagree }\end{array}$} & \multicolumn{2}{|c|}{ Disagree } & \multicolumn{2}{|c|}{ Agree } & \multicolumn{2}{|c|}{$\begin{array}{c}\text { Strongly } \\
\text { Agree }\end{array}$} & \multicolumn{2}{|c|}{ NA } \\
\hline & $n$ & $\%$ & $n$ & $\%$ & $n$ & $\%$ & $n$ & $\%$ & $N$ & $\%$ \\
\hline $\begin{array}{l}\text { Teachers have sufficient access } \\
\text { to appropriate instructional } \\
\text { materials. }\end{array}$ & 63 & 7.1 & 178 & 20.0 & 475 & 53.5 & 166 & 18.7 & 6 & 0.7 \\
\hline $\begin{array}{l}\text { Teachers have sufficient access } \\
\text { to instructional technology, } \\
\text { including computers, printers, } \\
\text { software and internet access. }\end{array}$ & 106 & 11.9 & 229 & 25.8 & 380 & 42.8 & 163 & 18.4 & 10 & 1.1 \\
\hline $\begin{array}{l}\text { Teachers have access to reliable } \\
\text { communication technology, } \\
\text { including phones, faxes and } \\
\text { email. }\end{array}$ & 30 & 3.4 & 97 & 10.9 & 520 & 58.6 & 237 & 26.7 & 4 & 0.5 \\
\hline $\begin{array}{l}\text { Teachers have sufficient access } \\
\text { to office equipment and supplies } \\
\text { such as copy machines, paper, } \\
\text { pens, etc. }\end{array}$ & 95 & 10.7 & 198 & 22.3 & 405 & 45.6 & 183 & 20.6 & 7 & 0.8 \\
\hline $\begin{array}{l}\text { Teachers have sufficient access } \\
\text { to a broad range of professional } \\
\text { support personnel. }\end{array}$ & 66 & 7.4 & 180 & 20.3 & 466 & 52.5 & 165 & 18.6 & 11 & 1.2 \\
\hline
\end{tabular}

\section{Table 4}

Means and Standard Deviations for Resource-Related Items and Scale by Grade Level

\begin{tabular}{|c|c|c|c|c|c|c|}
\hline \multirow{2}{*}{ Item } & \multicolumn{3}{|c|}{ Elementary } & \multicolumn{3}{|c|}{$\underline{\text { Middle }}$} \\
\hline & $n$ & $M$ & $S D$ & $n$ & $M$ & $S D$ \\
\hline $\begin{array}{l}\text { Teachers have sufficient access to appropriate } \\
\text { instructional materials. }\end{array}$ & 2547 & 2.96 & 0.77 & 882 & 2.84 & 0.81 \\
\hline $\begin{array}{l}\text { Teachers have sufficient access to instructional } \\
\text { technology, including computers, printers, } \\
\text { software and internet access. }\end{array}$ & 2536 & 2.84 & 0.86 & 878 & 2.68 & 0.91 \\
\hline $\begin{array}{l}\text { Teachers have access to reliable communication } \\
\text { technology, including phones, faxes and email. }\end{array}$ & 2546 & 3.11 & 0.69 & 884 & 3.09 & 0.71 \\
\hline $\begin{array}{l}\text { Teachers have sufficient access to office } \\
\text { equipment and supplies such as copy machines, } \\
\text { paper, pens, etc. }\end{array}$ & 2543 & 2.75 & 0.89 & 881 & 2.77 & 0.90 \\
\hline $\begin{array}{l}\text { Teachers have sufficient access to a broad range } \\
\text { of professional support personnel. }\end{array}$ & 2523 & 2.87 & 0.80 & 877 & 2.83 & 0.82 \\
\hline Statistics for Scale & 2472 & 2.91 & 0.64 & 855 & 2.85 & 0.65 \\
\hline
\end{tabular}

Research question 2 concerns the extent of the relationship between the mean results from the urban elementary and middle teachers' perceptions of five "resource-related" items and a scale mean derived from these items concurrent indices of student achievement at their schools. After aggregating individual teacher perceptions of resources to the school level, these school-level means were merged with publically-available "report card" data concerning each school's percentage of students proficient and advanced in Reading on the 2010 TCAP and each school's percentage of students proficient and advanced in Mathematics on the 2010 
TCAP.

Table 5

Means and Standard Deviations Computed from School-Level Teacher Responses for Resource-Related Items and Scale by Grade Level

\begin{tabular}{|c|c|c|c|c|c|c|}
\hline \multirow[t]{2}{*}{ Item } & \multicolumn{2}{|c|}{$\begin{array}{l}\text { Elementary } \\
(n=112)\end{array}$} & \multicolumn{2}{|c|}{$\begin{array}{l}\text { Middle } \\
(n=39)\end{array}$} & \multirow[t]{2}{*}{$t$} & \multirow[t]{2}{*}{$d$} \\
\hline & $M$ & $S D$ & $M$ & $S D$ & & \\
\hline $\begin{array}{l}\text { Teachers have sufficient access to appropriate } \\
\text { instructional materials. }\end{array}$ & 2.98 & 0.34 & 2.87 & 0.41 & 1.60 & 0.13 \\
\hline $\begin{array}{l}\text { Teachers have sufficient access to instructional } \\
\text { technology, including computers, printers, software } \\
\text { and internet access. }\end{array}$ & 2.87 & 0.38 & 2.76 & 0.51 & 1.44 & 0.12 \\
\hline $\begin{array}{l}\text { Teachers have access to reliable communication } \\
\text { technology, including phones, faxes and email. }\end{array}$ & 3.14 & 0.23 & 3.13 & 0.29 & 0.17 & 0.01 \\
\hline $\begin{array}{l}\text { Teachers have sufficient access to office equipment } \\
\text { and supplies such as copy machines, paper, pens, } \\
\text { etc. }\end{array}$ & 2.80 & 0.43 & 2.82 & 0.51 & -0.28 & -0.02 \\
\hline $\begin{array}{l}\text { Teachers have sufficient access to a broad range of } \\
\text { professional support personnel. }\end{array}$ & 2.91 & 0.28 & 2.85 & 0.38 & 0.97 & 0.08 \\
\hline Statistics for Five-Item Scale & 2.94 & 0.29 & 2.89 & 0.36 & 0.94 & 0.08 \\
\hline
\end{tabular}

As shown in Table 6, statistically significant relationships were observed between TCAP achievement levels and teacher responses to at least some of the items concerned school resources. When seen, such relationships were typically observed across the entire set of 147 schools having both sets of scores.

Table 6

Correlations between Resource-Related Item and Scale Means and Percent Proficient in TCAP Reading and Mathematics 2010 for All Schools and by Grade Level

\begin{tabular}{|c|c|c|c|c|c|c|}
\hline \multirow[t]{2}{*}{ Item } & \multicolumn{2}{|c|}{$\begin{array}{c}\text { All } \\
(N=147)\end{array}$} & \multicolumn{2}{|c|}{$\begin{array}{c}\text { Elementary } \\
(n=110)\end{array}$} & \multicolumn{2}{|c|}{$\begin{array}{l}\text { Middle } \\
(n=37)\end{array}$} \\
\hline & Read & Math & Read & Math & Read & Math \\
\hline $\begin{array}{l}\text { Teachers have sufficient access to } \\
\text { appropriate instructional materials. }\end{array}$ & 0.10 & 0.13 & 0.06 & 0.06 & 0.16 & 0.12 \\
\hline $\begin{array}{l}\text { Teachers have sufficient access to } \\
\text { instructional technology, including } \\
\text { computers, printers, software and } \\
\text { internet access. }\end{array}$ & 0.08 & 0.15 & 0.11 & 0.16 & -0.03 & -0.03 \\
\hline $\begin{array}{l}\text { Teachers have access to reliable } \\
\text { communication technology, including } \\
\text { phones, faxes and email. }\end{array}$ & 0.13 & 0.14 & 0.15 & 0.15 & 0.08 & 0.07 \\
\hline $\begin{array}{l}\text { Teachers have sufficient access to office } \\
\text { equipment and supplies such as copy } \\
\text { machines, paper, pens, etc. }\end{array}$ & $.18^{*}$ & 0.14 & 0.17 & 0.17 & 0.21 & 0.14 \\
\hline $\begin{array}{l}\text { Teachers have sufficient access to a } \\
\text { broad range of professional support } \\
\text { personnel. }\end{array}$ & $.20 *$ & $.22 * *$ & $.29 * *$ & $.23 *$ & -0.05 & 0.06 \\
\hline Correlations for Scale & 0.16 & $.18 *$ & 0.18 & 0.18 & 0.09 & 0.08 \\
\hline
\end{tabular}


With respect to the instructional resource items presented in Table 6, no significant relationships were observed at the middle school level between teacher responses to any of the resource-related items and TCAP achievement results in either Reading or Mathematics. However, with respect to the item concerning teacher "access to a broad range of support personnel," student outcomes in both Reading and Mathematics appeared to be linked to teacher perceptions both for all 147 schools $(r=0.20, r=0.22$, respectively) and for the subset of 110 elementary schools $(r=0.29, r=0.23$ respectively). For the entire set of schools, a relationship was observed between student outcomes in TCAP Mathematics and the mean obtained for the entire scale $(r=0.18)$ and between student performance in TCAP Reading and teacher access to office equipment and supplies $(r=$ $0.18)$.

\section{Discussion}

School climate not only affects students, it also affects teachers' sense of satisfaction and contributes to higher retention (Taylor \& Tashakkori, 1995). To meet the needs of higher retention of teachers in school districts, data driven budgets "help to ensure help ensure the effective use of resources to support and align effective practice across programs and educational departments" (Rennie Center Education Research \& Policy, n.d., p. 2). This study examined teachers' perceptions of the school climate elements of school resources and their relationship to student academic achievement in elementary and middle schools in an urban school district.

The researchers sought to identify aspects found in high achieving schools' climates that could attribute to their success. The literature identified multiple contributors; however, for this study the researcher analyzed the responses from classroom teachers by the use of a secondary data set related to the teachers' perception about the level of access to resources needed to achieve tasks in their everyday work. According to the data results analyzed related to elementary and middle school teachers' perception about the level of access they have to resources at their schools, both groups of teachers felt they have access to the resources where needed especially as it relates to communication technology, instructional materials, and support personnel. Although middle school teachers believe that access to instructional technology could be increased, in general, there were no reported differences between the teacher groups for any resource related items, thereby indicating that teachers believe they have adequate access to resources necessary to accomplish their instructional tasks.

The last set of data reviewed was the relationship between the mean results from elementary and middle school teachers' perceptions about the related items concerning school resources and that of schools whose achievement results were proficient in reading and math on the 2010 Tennessee Comprehensive Achievement Program (TCAP) assessment. All reading and math teachers believe that access to a broad range of support personnel could be strengthened, and reading teachers think they need better access to office equipment and supplies.

In light of the continuous search for school reform models that effectively consider all aspects of the school organizational structures, the researcher addressed considerations from the teachers' perceptions about their working environment and set out to determine if there was a relationship to student achievement. The aspects, of the school environment found in the literature and substantiated by the surveyed respondents that motivate teachers to perform at high academic standards is access to school resources.

Although, the literature indicates that the school climate does impact student achievement, it also identified that a learning environment must have certain attributes in order to facilitate effective teaching and learning. Based on the surveyed items related to resources, the responding teachers did not see these aspects as a major concern that hindered teaching and learning. As a result, the researchers ponder whether teachers have everything they need to increase student achievement; if there is truth to this belief, why are there only $50 \%$ of the respondents from schools that were proficient in reading and math? One interesting factor revealed in the study was that teachers who work at schools that had proficient scores in reading and math tend to have somewhat of different belief about some of the items related access to resources. These teachers believed that in 
order to meet the needs of each student and continue to have proficient scores they must have access to support personnel to assist when needed. On the other hand, teachers from low performing school also believed they had sufficient resources to meet the needs of all students, yet students did not score proficient in reading or math.

In comparison to the data results from this study and the review of the works from Herzberg (1959), the motivators that can influence teachers to perform at higher levels in urban schools are the possibility of achievement, also referred to as personal accomplishment, and the work itself of educating students. From the stance of the teachers, such motivators as human resources can serve as motivators for both elementary and middle school students. In contrast, such factors that could result in job dissatisfaction were not evident in any of the responses as a problem; however, severe constraints on access to resources could swiftly convert the motivators to inhibitors for the teachers. In conjunction, teachers who have experienced success in urban schools believe that academic success is obtainable and thereby expend extra efforts to accomplish it with available resources which substantiate the works of Herzberg (1959). Likewise, when success and high achievement is accomplished in similar settings, teachers tend be motivated to believe it can occur for them at their school.

\subsection{Implications for Principals as Instructional Leaders}

Urban schools continue to search for teachers who can make a difference in educating the students they serve. It is the role of the school leaders to provide a work environment that facilitates student success. Based on the information found in this study, elementary and middle school leaders in the Southeastern region of the United States should consider the following recommendations concerning the elements of the school climate as it relates to the level of access to resources in order to motivate teachers to achieve high levels of academic success for students. First, school leaders must consider allocating funds to purchase new technology, and provide access to technology and supplies for teachers to use at will to accomplish desired academic related task, as well as reliable internet access and computer-based instructional material to aid teaching and learning.

The researchers also deemed it necessary to provide specific recommendations to school leaders who lead schools that have proficient scores on TCAP in reading and math in order to perpetuate the results and monitor working dissatisfiers of the job do not impact performance. Therefore, school leaders should consider ways to individualize the instruction via a low number of students per class or support personnel available to assist in differentiating the instruction.

Acknowledgements: IRB approval was granted for this research study.

\section{References}

Cohen, J. (2009). Assessing school climate. Educational Digest, 74(8), 32-34.

Creswell, J. (2008). Educational research: Planning, conducting, and evaluating quantitative and qualitative research (3rd ed.). New Jersey: Prentice Hall.

Darling-Hammond, L. (2003). Keeping good teachers: Why it matters, what leaders can do. Educational Leadership, 60(8), 6-13.

Emerick, S., Hirsch, E., \& Berry, B. (2005). NCLB and teachers: Does highly qualified mean high-quality? ASCD Infobrief, 39, 1-8.

Freeman, D. J., \& Porter, A. C. (1989). Do textbooks dictate the content of mathematics instruction in elementary school? American Educational Research Journal, 26, 403-421. http://dx.doi.org/10.3102/00028312026003403

Gerwetz, C. (2014). The common core explained. Education Week. Retrieved from http://www.edweek.org/ew/issues/common-core-state standards/index.html?intc=main mpsmvs

Herzberg, F. (1959). The motivation to work. New York: John Wiley \& Sons.

Herzberg, F. (1966). Work and the nature of man. Cleveland, OH: World Publishing Company.

Hirsch, E., \& Church, K. (2009). North Carolina teacher working conditions research. Retrieved from 
Perceptions and relationships to school resources and academic achievement

http://ncteachingconditions.org/sites/default/files/attachments/NC_teacher_retention.pdf

Johnson, S., \& National Education Association. (2006). The workplace matters: Teacher quality, retention, and effectiveness. Brief: Summary of findings. New Teacher Center. Retrieved from http://ncteachingconditions.org/sites/default/files/attachments/NC_teacher_retention

Kloberdanz, K. (2010). California teachers: Pay for school supplies and more. Time, 7(1), 17.

Kober, N. (2001). It takes more than testing: Closing the achievement gap. A report of the center on education policy. Washington D.C. (ERIC Reproduction Service Number ED454358).

Leedy, P., \& Ormrod, J. (2012). Practical research: Planning and design (6 ${ }^{\text {th }}$ ed.). New York: Pearson Education.

Loukas, A., \& Roalson, L.A. (2006). Family environment, effortful control and adjustment among European American and Latino early adolescents. Journal of Early Adolescence, 26, 432-455. http://dx.doi.org/10.1177/0272431606291939

Loukas, A., \& Robinson S. (2004) Examining the moderating role of perceived school climate in early adolescent adjustment. Journal of Research on Adolescents, 14(2), 209-233. http://dx.doi.org/10.1111/j.1532-7795.2004.01402004.x

Marvel, J., Lyter, D., Peltola, P., Strizek, G., \& Morton, B. (2007). Improving teacher retention with supportive workplace conditions. Center for Comprehensive School Reform and Improvement, 1-4.

Moeller, B., \& Reitzes, T. (2011). Integrating technology with student-centered learning. Retrieved from http://www.nmefoundation.org/getmedia/befa9751-d8ad-47e9-949d-bd649f7c0044/integrating

National Education Association. (2008). Access, adequacy, and equity in education technology: Results of a survey of America's teachers and support professionals on technology in public schools and classrooms. Retrieved from https://www.edutopia.org/pdfs/NEA-Access,Adequacy,andEquityinEdTech.pdf

Noeth, R. J., \& Volkov, B. B. (2004). Evaluating the effectiveness of technology in our schools act: Policy report. Retrieved from http://www.act.org/research/policymakers/pdf/school tech.pdf

Pan, D., Rudo, Z. H., Schneider, C. L., \& Smith-Hansen, L. (2003). Examination of resource allocation in education: Connecting spending to student performance. Retrieved from http://www.sedl.org/pubs/policyresearch/policydocs/Examination.pdf

Patton, M. (2007). How to use qualitative methods in evaluation. London: Sage Publications.

Pearson. (2014). Student mobile device survey. Retrieved from http://www.pearsoned.com/wp-content/uploads/Pearson-K12-Student-Mobile-Device-Survey-050914-P BLIC-Report.pdf

Pitler, H. (2007). Using technology with classroom instruction that works. Alexandria, VA: Association for Supervision and Curriculum Development.

Plecki, M. L., Knapp, M. S., Castaneda, T., Halverson, T., LaSota, R., \& Lochmiller, C. (2009). How leaders invest staffing resources for learning improvement. Retrieved from http://www.wallacefoundation.org/knowledge-center/school-leadership/district-policy-and-practice/Pag es/How-Leaders-Invest-Staffing-Resources-for-Learning-Improvement.aspx

Rennie Center Education Research \& Policy. (n.d.). Smart school budgeting: Resources for districts. Retrieved from http://www.renniecenter.org/research/SmartSchoolBudgeting.pdf

Seels, B., \& Richey, R. (1994). Instructional technology: The definition and domains of the field. Washington, D.C.: Association for Educational Communications and Technology.

Shindler, J., Jones, A., Taylor, C., \& Cadenas, H. (2004) Does seeking to create a better classroom climate lead to student success and/or improved teaching? Examining the relationship between pedagogical choices and classroom climate in urban secondary schools. Paper presented at the AERA, San Diego.

Swanlund, J. (2010). Tell Tennessee teaching working conditions survey. Retrieved from http://www.Tennessee.gov/education

Swanlund, J. (2011). Tell Tennessee teaching working conditions survey. Retrieved from http://www.Tennessee.gov/education

Tashakkori, A., \& Teddlie, C. (1998). Mixed methodology: Combining qualitative and quantitative approaches (Applied Social Research Methods Series, Vol.46). London: Sage.

Taylor, D., \& Tashakkori, A. (1995). Participation in decision making and school climate as predictors of 
Boudreaux, M. K., Martin, R., \& McNeal, L.

teachers' job satisfaction and sense of efficacy. Journal of Experimental Education, 63 (3), 217-233. http://dx.doi.org/10.1080/00220973.1995.9943810

TELL Tennessee. (2012, May). Validity and reliability of the 2011 Teaching, Empowering, Leading and Learning (TELL) Tennessee Survey. Retrieved from

http://telltennessee.org/sites/default/files/attachments/TN11_valid_reliable.pdfYork, J., \& Vandercook, T. (1990). Strategies for achieving an integrated education for middle school students with severe disabilities. Remedial and Special Education, 11(5), 6-15.

York, J., Giangreco, M. F., Vandercrook, T., \& Macdonald, C. (1992). Integrating support personnel in the inclusive classroom. In S. Stainback \& W. Stainback, (Eds.), Curriculum considerations in inclusive classrooms: Facilitating learning for all students (pp. 101-116). Baltimore, MD: Paul H. Brookes Publishing. 